UDK: 316.772.4::616-053.9

Izvorni naučni rad

Primljeno: 12. 9. 2019.

Prihvaćeno za štampu: 13. 1. 2020.

dr. sci. Emin Mesić, docent

Internacionalni univerzitet u Travniku

E-mail:tvusk@net.hr

dr. sci. Sena Družić, docent

Univerzitet u Bihaću

E-mail:sena_druzi@@yahoo.ca

dr. sci. Mirsada Terzić-Avdagić, vanredni profesor

\title{
ZNAČAJ INTERPERSONALNE KOMUNIKACIJE U PROCESU ZAŠTITE I NJEGE STARIH OSOBA
}

\section{Sažetak}

Komunikacija kao socijalni fenomen, umnogome zavisi o broju učesnika koji razmjenjuju poruke, kao $i$ njihove interakcije, koja se odvija na intrapersonalnom i interpersonalnom nivou. Cilj ovog naucnog rada bio je istražiti, analizirati i predstaviti činjenice, koje su važne za komunikacijske odnose u procesu zaštite i njege starijih osoba. U svakoj situaciji u kojoj je čovjek osnovni subjekt komunikacijskog procesa ne smije se zanemariti komunikacija koja je usmjerena na unutrašnje ponašanje pojedinca odnosno komunikaciju unutar osobe ili razgovor sa samim sobom. U svakodnevnom komuniciranju većina ljudi najviše polaže pažnju na ono što se kaže, ne vodeći pri tome računa na koji je način to rečeno. Zar treba podsjećati da lijepa riječ, uz osmjeh, razbija sve barijere u ljudskoj komunikaciji. To može biti izuzetno ljekovito onima koji se nalaze u trećoj životnoj dobi i koji su upućeni na pomoć drugih. $U$ istraživanju je korištena metoda teorijske analize, a predstavljena su $i$ istraživanja na temu značaja interpersonalne komunikaciju u gerijatrijskim i gerontološkim institucijama. Istraživanje je pokazalo, pozitivno zapažanje, gdje se ističe odnos zaposlenih u ustanovama za smjestaj i zbrinjavanje starih osoba prema ovim osobama $i$ njihova potpuna posvećenost korisnicima usluga $u$ njihovom najboljem interesu, te human odnos $i$ poštovanje njihovog dostojanstva što su u svojim izjavama isticali brojni korisnici usluga ustanova. 


\section{Ključne riječi: interpersonalna komunikacija, recepijent, empatija, gerijatrija, gerontologija, starije osobe.}

\section{Uvod}

Intrapersonalno komuniciranje može se shvatiti kao produžetak interpersonalne komunikacije (koncipirane kao dijaloški organizirani razgovor) i kao posrednički nivo u recepciji poruka u procesu masovnog komuniciranja. Elementarnost i rasprostranjenost interpersonalnog komuniciranja prisutnog u svakodnevnici svakog čovjeka, proističe iz samog našeg karaktera svojstvenog samo ljudskom socijalnom biću. Komunikacija ne postoji sama po sebi, već radi toga da bi se postigao određeni cilj, odnosno da bi se ostvarila svrha komuniciranja. Socijalni fenomen interpersonalne komunikacije ogleda se u njenoj mogućnosti da i sama pomaže boljem organiziranju ljudi. Članovi organizacije komunicirajući $s$ drugim recipijentima na grupnom i individualnom nivou, potiču ili smanjuju pruduktivnost rada, oblikuju međuljudske odnose i utiču na individualni ili grupni razvitak (Reardon, 1998: 169).

Recepijenti (bolesnici, osobe starije životne dobi), sasvim sigurno će bolje prihvatiti stručnjaka (liječnika, socijalnog radnika) koji je iskren i ljubazan, koji svojim lijepim, jasnim i razumljivim govorom i govorom tijela pokazuje da je tu prisutan radi činjenja dobra, te da mu je stalo do pružanja pomoći onome kome je to potrebno. Nasuprot tome, postoje osobe koje već povišenim glasom i svojim ukočenim stavom žele da nametnu autoritet i dominantnost, čime ometaju i sprečavaju uspostavljanje željenog interpersonalnog komunikacijskog procesa. Od takvih osoba je nemoguće očekivati produkcije empatije, budući da oni već na startu svojim ponašanjem stvaraju komunikacijske barijere i proizvode buku i šumove u komunikacijskim kanalima.

Sve veća pažnja se posvećuje komunikacijskim potrebama koje se pružaju u kontekstu zdravlja. Liječnik je samo jedan od izvora informacija o bolesti. Pacijenti se služe i neformalnim vezama da bi doznali kako reagirati na bolest i kako je spriječiti. Zdravstveno komuniciranje utiče na svakog od nas. Masovni mediji i interpersonalni komunikacijski kanali mogu proširiti svijest o postupcima koji pomažu održavanju zdravlja i ujedno promjeniti naša ponašanja tamo gdje je to potrebno. U savremenoj teoriji i praksi te se promjene najviše osjećaju 
u sve boljem i humanijem odnosu prema osobama starije životne dobi, gdje se problemu interpersonalnog komuniciranja u gerijatrijskoj djelatnosti poklanja posebna pažnja.

Ako razgovor sa recipijentom (pacijentom ili osobom za potrebom socijalne zaštite), posmatramo kao komunikacijski proces, tada je na jednom kraju pošiljalac poruke, a na drugom primalac - recipijent (starija osoba u stanju socijalne ili zdravstvene potrebe). Između njih se odvija vrlo složena komunikacijska dinamika. Liječnik ili socijalni radnik, kada imaju namjeru poslati određenu poruku, oni je najprije zamisle, a potom pretvore u verbalnu poruku. Da bi verbalna (govorna) poruka došla do recipijenta, on je mora čuti i razumijeti. To mogu otežati mehaničke smetnje (šumovi, nejasan i tih govor), ali i semantičke smetnje (nerazumljiv sadržaj). Ako se te smetnje uklone ili ih uopće nema, poruka dolazi do recipijenta, koji je prima, interpretira i pretvara u vlastiti stav o datom problemu, što je polazna osnova za tzv. povratnu spregu (fedd back) kao prvi korak na putu do empatije.

Empatija kao način komuniciranja u području socijalne psihologije postupno je privlačila i pažnju komunikologa kao važan preduvjet socijalizacije određenih društvenih grupa. Stoga se danas u interpersonalnoj komunikaciji govori i o empatijskom načinu komuniciranja, pogotovo u nekim specijalnim vrstama intervjua, gdje se od komunikatora traži sposobnost uživljavanja u emocionalna stanja druge osobe i razumijevanje njenog položaja. Danas se termin empatija najviše koristi u kliničkoj i socijalnoj psihologiji. U kliničkoj psihologiji empatija se tretira kao proces koji služi komunikacijskim funkcijama u terapiji. Psiholozi, međutim, imaju kognitivni pristup, razumijevanje i poznavanje stanja svijesti ili uvjeta u kojima se nalazi druga osoba, odnosno podizanje svijesti o tome šta se događa u drugoj osobi.

Gerijatrija je grana medicine, koja se bavi promoviranjem zdravlja, prevencijom i liječenjem oboljenja starih lica.Izraz dolazi od riječi ", geron“( starac ) i , jatros ,,( ljekar ) ( Šarić, Družić, 2016; prema Klaić, 1978).

Gerontologija je naučna disciplina koja proučava starost i sve aspekte ( fiziološke, medicinske, psihološke, socijalne, pravne, antropološke ) promjene, do kojih dolazi u procesu starenja. Izraz dolazi od (grčki: 
gerontos-starac i logos-znanost). Dok je socijalna gerontologija interdisciplinarna grana gerontologije, koja se specijalizirala za proučavanje socijalnih zakonitosti starenja i rada sa starim osobama. Isto tako socijalna gerontologija se bavi edukacijom, istraživanjem i unapređenjem života starih osoba ( Šarić, Družić, 2016; prema Schaie i Willis, S. L. 2001).

Prema definiciji Svjetske zdravstvene organizacije stariji su ljudi od 60 do 75 godina, stari od 76 do 90 godina, a vrlo stari ljudi su oni koji imaju više od 90 godina (Duraković i dr., 1990).

Još uvijek ne znamo odgovor na pitanje zašto ostarimo. Razne teorije starenja samo djelomično zadovoljavaju naše razumijevanje procesa i izdaleka nam ne daju nade da bismo mogli napraviti smislen i svrhovit pokušaj djelovanja na tu pojavu. Iz genetske i fiziološke teorije starenja, tradicionalno je gledište da je biološka involucija žive materije neizbježan i gotovo nepovratan proces (Hodoba, 1995).

Naučni rad koji ima za cilj istražiti, analizirati i predstaviti činjenice, koje su važne za komunikacijske odnose u procesu zaštite i njege starijih osoba, konkretno o značaju interpersonalne komunikacije u procesu zaštite i njege starijih osoba, s akcentom na vještine stručnih osoba u socijalnom radu i zdravstvenoj djelatnosti, pored znanja i iskustava u postizanju empatije, važno je naglasiti i značaj umijeća postavljanja pitanja, te razumijevanje fenomena aktivnog slušanja. U procesu razmjene komunikativnih sadržaja na relaciji dvosmjernog reverzibilnog postavljanja pitanja i očekivanja odgovarajućih odgovora, postiže se: dobivanje željenih informacija, povećanje jasnoće komunikacije, uspostavljanje i održavanje kontakata, pokazivanje sagovorniku da ga slušamo, te usmjeravanje razgovora u okvire teme (Mesić, 2013: 74).

\section{Karakteristike komunikacijskog procesa u socijalnom radu s osobama treće životne dobi koje borave u socijalno-gerijatrijskim centrima}

Socijalni rad, kao praktična društvena djelatnost, razvijao se od nastanka čovječanstva i njegove spontane, urođene reakcije na pomoć i pomaganje drugome. Danas je socijalni rad prerastao u naučnu disciplinu čiji je predmet bogat, raznovrstan i promjenjiv i koji u svome 
radu koristi rezultate i naučna saznanja većeg broja nauka. Socijalni rad u socijalnim ili socijalno-zdravstvenim ustanovama za zbrinjavanje starijih osoba ima specifičnosti zavisno od karaktera i zadataka ustanove, njene organizacije $\mathrm{i}$ drugog, a treba biti zastupljen $\mathrm{u}$ njegovom radu s klijentom od samog dolaska štićenika u ustanovu, pa eventulano do njenog izlaska iz sistema institucionalnog zbrinjavanja i povratka u socijalnu sredinu u kojoj je živio. Prema Dervišbegoviću (2001: 45), socijalni rad u ustanovama socijalne zaštite ima sljedeće zadatke: pripremu za dolazak i prijem štićenika u ustanovu, rad na prilagođavanju štićenika u uslovima nove sredine, organizovanje života i angažovanje štićenika raznovrsnim aktivnostima, praćenje i tretman štićenika u ustanovi, priprema štićenika za odlazak iz ustanove (ukoliko nisu trajno zbrinuti), praćenje štićenika poslije eventualnog odlaska iz ustanove i pomoć u uključivanju u novu socijalnu sredinu.

Kod prijema korisnika u ustanovu, socijalni radnik, ukoliko nije utvrdio ranije te podatke, utvrđuje razloge štićenikovog smještaja, socijalne, materijalne, zdravstvene i druge prilike iz kojih štićenik dolazi, njegove lične stavove, poglede, navike i slično, koji su potrebni za dalji rad sa štićenikom. Posebno je važno naglasiti da socijalni radnik, treba imati dovoljno znanja o komunikacijskim vještinama, koje će primijeniti pri prijemu starije osobe. Socijalni radnik u domu za stare i nemoćne osobe prilikom dolaska korisnika u novu sredinu pomaže u razdoblju prilagodbe na način da upoznaje korisnika s prostornim rasporedom doma, dnevnim rasporedima i slično, motivira korisnika za upoznavanje s drugim korisnicima i stvaranje novih socijalnih veza, vrši opservaciju i prema tome donosi procjenu o odgovarajućem obliku podrške i pomoći za pojedinog korisnika, pruža odgovarajuću podršku i pomoć u prilagodbi na život u novoj sredini. Socijalni radnik u posrednoj ili neposrednoj saradnji s korisnikom istražuje korisnikove svakodnevne potrebe, te mu pruža potrebnu pomoć i podršku pri zadovoljavanju istih (Rusac, Čizmin, 2011: 77).

Zavisno od njegovih mogućnosti, interesa i potreba, uključuje ga u odgovarajuću grupu za okupaciono-radnu terapiju, kulturno-zabavni ili sportski život i slično, čime pomaže njegovoj integraciji u ustanovi. Socijalni rad u socijalnim ustanovama mora biti planiran i programiran, a u njegovoj realizaciji socijalni radnik se mora pridržavati svih načela socijalnog rada, a metode stvaralački primjenjivati vodeći računa o 
specifičnostima socijalnog rada u socijalnim ustanovama. U radu će pored ostalih naročito primjenjivati rad s pojedincem, grupni rad, te administraciju i dokumentaciju u socijalnom radu (Dervišbegović, 2001: 145).

$\mathrm{U}$ vezi s tim socijalni radnik mora, pored dobrog poznavanja komunikacijskih vještina, solidno vladati i s komunikacijskom kulturom, znanjima i vještinama iz poslovne komunikologije. Komuniciranje u poslovnoj sredini je složen dinamički proces koji svoje osnovne ciljeve ostvaruje unutar same organizacije i između poslovne grupe i okruženja. Organizacijski proces komuniciranja omogućava upravljanje svim aktivnostima organizacije u željenom pravcu, odnosno određuje ponašanje i primalaca i komunikatora da djeluju ka ostvarivanju zajedničkih ciljeva. Dobra komunikacija u socijalnom radu, uz adekvatnu motiviranost zaposlenih, obezbjeđuje donošenje dobrih odluka i njihovu uspješnu realizaciju.

Današnje ustanove za smještaj se sve više razvijaju i otvaraju u pravcima vaninstitucionalnih oblika zbrinjavanja. Gerontološki centar u Sarajevu, naprimjer, osim smještaja u dom i prihvatilište, nudi i vaninstucionalne usluge za stare osobe - dnevni centar i programi kućne njege i pomoći u kući, u okviru kojih su zadaci socijalnog rada sljedeći: obavljanje poslova stručnog socijalnog rada s korisnicima usluga, pružanje stručne pomoći korisnicima uz individualni i grupni rad, s ciljem pružanja socijalne i emocionalne podrške i sigurnosti korisnika usluga, obavljanje poslova vođenja odgovarajuće evidencije i dokumentacije u vezi s korisnicima usluga, obavljanje poslova koja se dovode u vezu s organizacijom radno-okupacijskih, kulturno-zabavnih i rekreativnih aktivnosti korisnika, vršenje praćenja zdravstvenog stanja korisnika i drugih promjena koje utiču na njegov status i promjenu cijene usluga, praćenje naplate usluga, rad sa strankama, rad na prijemu korisnika u prihvatilište i obavljanje stručnih i administrativnih poslova, rad na uključivanju u usluge kućne njege i pomoći u kući koji prije zaključenja ugovora podrazumijeva obaveznu posjetu potencijalnom korisniku u njegovom stanu/kući, stručni socijalni rad na terenu, pojedinačna analiza svakog posjećenog lica i procjena zatečenog stanja s prijedlogom za preduzimanje adekvatnih mjera, vođenje evidencije vezane za pružanje usluga $u$ institucionalnim i vaninstitucionalnim oblicima zaštite, obavljanje administrativnih 
poslova i radnji koje je neophodno provesti nakon smrti korisnika usluga domskog smještaja (sačinjavanje smrtovnice, upisi u matičnu knjigu umrlih, kontakti s porodicom, matičarima), kao i administrativni poslovi nakon prestanka ili raskida ugovora o korištenju usluga (http://gcs.com.ba/).

Socijalni radnik više radi s klijentom, nego za klijenta i stoga je poželjna, a u skladu s njihovim psiho-fizičkim sposobnostima, što veća klijentova lična uključenost i aktivnost u donošenju odluka koje se odnose na njih same. Rad s klijentom bazira se na dobrim verbalnim i neverbalnim komunikacijskim vještinama socijalnog radnika koje dovode do uspostavljanja povjerenja i dobrog razumjevanja sa starijom osobom smještenom u gerijatrijskom centru (ustanovi). $U$ tom pogledu naročito je važno dobro empatijsko komuniciranje kao način da se svakodnevno osluškuju želje i potrebe osoba s posebnim socijalnim zahtjevima i potrebama. Socijalni radnik mora dobro da razumije neverbalne signale koji pokazuju misli i emocije, stavove i osobine gerijatrijskih klijenata. Pokreti otkrivaju i govore o rasploženjima i stanjima, omogućavaju da izraze slaganja ili neslaganja, prihvatanje ili odbijanje i slično.

Institucija ombudsmena za ljudska prava Bosne i Hercegovine, objavila je Specijalni izvještaj o stanju ljudskih prava starih osoba. Ombudsmeni su odlučili da posjete ustanove za zbrinjavanje starijih osoba kao jedini mogući način provjere stanja njihovih ljudskih prava. Rezultat ovih posjeta predstavlja jedini indikator stanja ljudskih prava građana starije dobi, a vjerovatno je da je ono još i gore kad su u pitanju ljudska prava ostalih starih osoba koje su izvan sistema ustanova. Posjete ustanovama, kao i iskustva u radu po žalbama i u javnosti, te općepoznate činjenice vezane za položaj starih, a među njima posebno iznemoglih, od porodica napuštenih, siromašnih i ugroženih, bile su razlog da se sačini ovaj Specijalni izvještaj o pravima starih osoba. Nepostojanje adekvatnog i posebnog normativnog okvira o podršci starim ljudima u ostvarivanju njihovih ljudskih prava, činjenica da se društvo brine o relativno malom broju starih ljudi kroz socijalnu pomoć ugroženim, uglavnom smještenim u domove i druge ustanove kojih nema dovoljno, a neke su i izvan sistema socijalne zaštite, te ocjena o postojanju ugroženosti i socijalne otuđenosti jednog broja starih osoba, bili su razlog da ombudsmeni sačine ovaj izvještaj (www. 
Diskriminacija.ba; posjetila 26. 11. 2019). Nekih većih istraživanja po predmetnoj temi naučnog rada, nije ni bilo, na nivou Bosne i Hercegovine.

Promjene demografske strukture stanovništva, društveno-politička kretanja, odlazak mladog stanovništva iz Bosne i Hercegovine, definitivno nameće potrebe za razvijanjem i unapređenjem dobre komunikacije sa starim osobama, i razvijanjem institucionalnih mehanizama koji će pomoći starim osobama da zadovolje te potrebe, da duže budu živi, zdravi i aktivni. Sva pomenuta unapređenja su nužno potrebna zbog činjenice da današnje stare osobe imaju dosta veće i raznovrsnije životne zahtjeve u odnosu na prethodne generacije. Stare osobe ne treba percipirati kao problem i opterećenje u društvu, već kao resurs iskustva, mudrosti i znanja koji je i dosad davao veliki doprinos u društvenom razvoju. Starost je prirodno stanje koje podrazumijeva specifične potrebe. Starenje ne znači gubitak sposobnosti i pojavu bolesti.

Duži, zdraviji i kvalitetniji život stanovništva su društvena dostignuća nastala kao rezultat boljih životnih i radnih uslova, poboljšane prehrane, higijene, zdravstvene zaštite itd. Za postizanje ovakvih ciljeva potreban je doprinos svih osoba, kao i starijih, koje je potrebno uključiti u sve društvene tokove zajednice, posebno u one sfere koje se tiču lično njih, njihovog položaja i njihovih prava. Ovo predstavlja vremenski pristup zaštite starijih osoba i jedno je od njihovih osnovnih ljudskih prava. Poticanje aktivnosti kod starijih ljudi, korištenje kvalitetnih komunikacijskih vještina socijalnog radnika i osobe treće životne dobi, temelji su prevencije njihovih socijalnih i zdravstvenih problema, a realizira se kroz poboljšanje uslova života i zdravstvenih navika koje mogu spriječiti preranu pojavu bolesti, a provođenje ugodnih i sretnih dana, osoba u trećoj životnoj dobi.

Viđenje života u starosti, pak, određuje naše stavove prema starim osobama i njihovom mjestu u društvu. Biološko starenje je neminovno, pa je onda bolje da ga dočekamo spremni, nego da se borimo protiv njega. Naše tijelo stari, ali naše sposobnosti prilagodbe, kako na gubitke tako i na nove izazove, stalno se razvijaju (Šarić, Družić, 2016).

U svemu ovome uloga socijalnog radnika, odnosno njegova znanja i vještine verbalnog i neverbalnog komuniciranja s osobama u trećoj 
životnoj dobi, mogu znatno olakšati sveukupnu situaciju i unaprijediti rad u gerijatrijskoj ustanovi. Polazeći od činjenice da je permanentni interpersonalni kontakt, stalna interakcija i neposredan razgovor osnovni oblik verbalne komunikacije, nužno se pridržavati govorničkih pravila, prilagoditi jezik slušaocu i učiniti da poruka bude jednostavna i direktna. Za održavanje dobre i kvalitetne komunikacije s osobama starije životne dobi, važno je, također, ne opterećavati slušaoca nepotrebnim i nevažnim informacijama i digresijama, već pružati ključne informacije, i izbjegavati detalje i suvišne riječi. Jednostavno, komunikacija u socijalnom radu i svakodnevnoj praksi mora da bude kratka, jasna i razumljiva.

\section{Komunikacijske vještine medicinskog osoblja u pružanju zdravstvenih usluga starijim osobama}

Značaj komunikacijskih vještina medicinskog osoblja s osobama starije životne dobi je vrlo zahtjevan prvenstveno jer su to vrlo senzibilne, i u psihološkom smislu, ranjive osobe, te ne postoji univerzalni model $u$ komunikaciji s njima. Komunikacija zahtijeva individualni pristup svakom posebno, s obzirom da potiču iz različitih kultura življenja i različitog odnosa prema zdravlju i bolesti. Takav pristup se mora održati tokom prvog ili svakog ponovnog susreta ili hospitalnog tretmana, ili neke druge medicinske usluge sve do povratka u porodicu ili ustanovu u kojoj je živio. Isti tretman je potreban i kod osoba starije dobi trajno smještenih u gerijatrijskim ustanovama, s kojima je komunikativni odnos još specifičniji, a individualni pristup još zahtjevniji.

Fiziološko ili primarno starenje može se definirati kao sposobnost prilagođavanja na uvjete okoline, najčešće sljedećim parametrima: izdržljivost, jakost, fleksibilnost, koordinacija i radni kapacitet. Iako promjene počinju početkom četvrtog desetljeća, ustroj i funkcija pojedinih unutrašnjih organa za trećinu se smanjuju u dobi od oko 65 godina. No, najmanje 50\% promjena koje se pripisuju primarnom starenju posljedice su atrofije zbog neaktivnosti. Primjer su otežan hod i slabija pokretljivost. Struke koje se bave tim područjima su gerontologija i gerijatrija(1). Gerijatrija-(grč. $\gamma \varepsilon ́ p \omega v-$ geron $=$ stari +

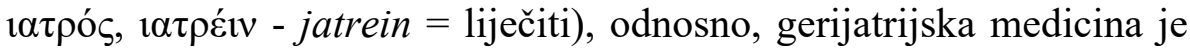
proučavanje starenja ili liječenja bolesti u svim njenim dimenzijama 
uključujući socijalne, ekonomske, demografske, kulturne, psihološke, medicinske i druge fenomene.

HIstorijski gledano, razvoj gerontološke i gerijatrijske misli i prakse potiče od antičkih grčkih filozofa: Hipokrata, Platona i Galena, koji su još u starom vijeku iznosili svoja razmišljanja o zdravstvenim problemima čovjeka. Tako, naprimjer, Hipokrat (460-370. p.n.e.) smatra da stariji ljudi boluju od hroničnih bolesti koje traju sve do smrti, te ih je locirao na pluća, bubrege, zglobove, vid i sluh. S druge strane, Platon (427-347. p.n.e.) je govorio da stari treba da vladaju kako bi se spriječile novotarije, dok je Galen (129-199) identifikovao smanjenje tečnosti kao uzrok smanjenja tjelesne toplote. On je, također, prvi spoznao da starost nije bolest, ali nije ni zdravlje, što je jedna od premisa na kojima se zasniva savremena gerijatrija: „starost nije jednako bolest“. I čuveni renesansni učenjak i umjetnik, Leonardo da Vinci (1452-1518), zorno je na svojim crtežima prikazao promjene krvnih žila kod osoba starije životne dobi.

Savremeni gerijatri posjeduju specifična stručna znanja i vještine koje su neophodne da bi se dostigli visoki profesionalni standardi u domenu, kako akutnog, tako i hroničnog zbrinjavanja, njege $\mathrm{i}$ rehabilitacije starijih pacijenata. $U$ tom pogledu treba razmatrati i ulogu i značaj verbalne i neverbalne komunikacije u zdravstvu. Znati se približiti osobi koja dolazi na pregled, a ne vidi, znači treba prvo pridobiti povjerenje da će ga osoba kojoj se obratila razumjeti. Zato uvijek treba pružiti ruku da osjeti toplinu i biskost, a zatim drugu ruku staviti na naslon stolice da shvati da je dobro došao. Tek tada se može očekivati da će osoba pričati o svom problemu. Jako je teško komunicirati i s osobom koja ne čuje, ali se može koristiti mimika i gestikulacuja, uz čiju pomoć se vrlo brzo osjeti i uspostavlja saradnja.

Istraživanja su pokazala da se većina zamjerki bolesnika na zdravstvenu službu odnosi upravo na nezadovoljavajuću komunikaciju sa zdravstvenim djelatnicima, a malo kad se bolesnici žale na njihovu nestručnost. Dobra komunikacija zdravstvenih djelatnika i bolesnika mora biti uspostavljena već u ambulanti. U bolničkom liječenju komunikacija s bolesnikom često ima psihoterapeutsko značenje. Svaki odlazak u bolnicu kod bolesnika uzrokuje loša emocionalna stanja, najčešće tjeskobe i potištenost. Mnogi primjeri iz bolničke prakse pokazuju pozitivne učinke empatije na tok bolesti, kao što je slučaj $s$ 
oslovljavanjem bolesnika njegovim imenom (isto je, također, važno bolesniku reći svoje ime). „Ko je oslovljen vlastitim imenom, taj više nije anoniman“, nije brojka, neće biti zaboravljen i biće liječen kao jedinka. Ako je bolesnik oslovljen imenom, onda je to znak da ga poznajemo kao osobu, da su liječnicima, medicinskim sestrama i zdravstvenim djelatnicima poznati njegovi problemi i njegova specifična situacija.

Jedan od najvažnijih ishoda uspješne komunikacije između liječnika i bolesnika je sticanje poštovanja, a time i povjerenja bolesnika $u$ liječnika i cijeli zdravstveni tim koji brine o njemu. Pojam komunikacijskih vještina treba razlikovati od pojma sposobnosti. Vještine predstavljaju naučeni, odnosno učenjem i prakticiranjem stečeni dio ponašanja, dok je sposobnost preduslov za ostvarivanje vještina. Upravo stoga, sposobnost komuniciranja nije stečena sposobnost, već vještina koju bi zdravstveni radnici trebali učiti i redovno prakticirati.

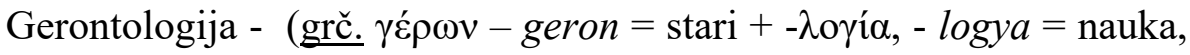
znanost, proučavanje) je nauka o biološkim, psihološkim i društvenim procesima i pojavama starenja. Gerontologija obuhvaća praćenje, proučavanje, evaluaciju, planiranje, projekciju, te izvještavanje o zdravstvenim potrebama i funkcionalnoj sposobnosti starijih osoba $\mathrm{u}$ ranijoj (65 do 74 godine), srednjoj ( 75 do 84 godina) i dubokoj starosti (85 i više godina). Pod starenjem se podrazumijeva proces tokom kojega se događaju promjene u funkciji dobi. Imala sam primjer gdje mi je pacijent sa 75 godina rekao da nije star. I u pravu je. Ne osjeća se staro. Obično se grubo razlikuju tri osnovna vida starenja:

- biološko, odnosno promjene, usporavanje i opadanje u funkcijama organizma s vremenom; - psihološko, odnosno promjene u psihičkim funkcijama i prilagodba ličnosti na starenje; - socijalno, odnosno promjene u odnosu pojedinca koji stari i društva u kojem živi.

Pojam starenja obuhvata hronološko starenje kao glavna odrednica promjena u procesu starenja (Baltes i Willis, 1977). Danas znamo da određeni vidovi inteligencije u starosti ne moraju opadati, nego mogu rasti. (Naprimjer: Moj prof. Mirko Grujić iz interne medicine je rekao da sada drži bolja predavanja nego što je držao nama). Uzrok opadanja inteligencije $u$ nekim se slučajevima može otkloniti, npr., ako 
sposobnost slabi zbog smetnji u optoku krvi u mozgu. Historijski gledano, moguće je da je inteligencija u prijašnjim generacijama opadala u starosti zbog slabih mogućnosti obrazovanja tih generacija ili zbog očekivanja tadašnjeg društva da stara osoba odustane od intelektualnih aktivnosti. Na psihološkom nivou razlike su još veće, bilo unutar pojedinca, bilo među raznim pojedincima.

U pokušajima određivanja prave prirode starenja, obično se razlikuje primarno i sekundarno starenje. Primarno starenje ili fiziološko starenje se odnosi na normalne, fiziološke procese koji su određeni unutarnjim, biološkim faktorima koji su neizbježni i posljedica su sazrijevanja ili protoka vremena, kao, naprimjer, menopauza kod žena ili hipotrofija musculature. Sekundarno starenje odnosi se na patološke promjene i opadanje s godinama koje je posljedica vanjskih faktora, zračenje, kao npr. utjecaj buke na slabljenje sluha (prema: Lemme, 1995).

Problemi u komunikaciji sa starijim osobama dovode do njihove fizičke, psihičke i socijalne dekompenzacije. Posebne teškoće pričinjava komunikacija sa slabovidnim, slušno oštećenim i osobama oboljelim od demencije koja iziskuje posjedovanje dodatnih specijalističkih znanja i vještina. Pravilnom komunikacijom ostvarujemo potreban kontakt, kako bismo mogli preuzimati adekvatne mjere za zdravstvenu zaštitu starih i nemoćnih osoba. Jer, svaki čovjek u svojoj okolini, svakodnevno je u prilici da komunicira sa starijim osobama, bilo da su u pitanju vlastiti roditelji, djed i baka, poznanici ili su to, pak, naši štićenici u odgovarajućoj socijalnoj ili zdravstvenoj ustanovi. U većini slučajeva komunikacija sa starijima bi se trebala odvijati na isti način na koji komuniciramo s mlađim osobama. Međutim, često postoje komunikacijske prepreke, budući da je komunikacija sa starim osobama izložena brojnim teškoćama.

\section{ZAKLJUČCl:}

Postavljeni cilj ovog naučnog rada je realiziran, jer smo istražili, analizirali i predstavili činjenice, koje su važne za komunikacijske odnose $u$ procesu zaštite i njege starijih osoba. Prije svega jer smo utvrdili da uspješna komunikacija pomaže, da bolje razumijemo ljude i životne situacije, da prevladamo predrasude i različitosti, da gradimo povjerenje i poštovanje jednih prema drugima, te da stvaramo uslove za razmjenu kreativnih ideja i rješavanje problema. Iako se komunikacija 
sama po sebi čini jednostavnom, često dolazi do nerazumijevanja kada želimo uspostaviti komunikaciju s drugima ili drugi s nama, što može uzrokovati konflikte i frustracije u privatnom i profesionalnom životu i općenito u odnosima s ljudima. Komunikacija je kompleksan proces koji uključuje: slanje i primanje poruke upućene pojedincu ili grupi, te podrazumijeva sigurnost i prepoznavanje da je poruka prihvaćena $\mathrm{i}$ shvaćena na pravi način (s razumijevanjem), kako bi se izbjegli nesporazumi koji mogu kompromitirati poslanu informaciju, odnosno cjelokupni komunikacijski proces.

Savremeni razvoj komunikacijske tehnike i tehnologije proširuje kontekst u kojem se odvija komunikacijski proces u zdravstvenoj i socijalnoj djelatnosti. On nije više vezan isključivo za tradicionalni način komuniciranja, tzv. komuniciranje „licem u lice“ (face to face), nego se sve više koriste i drugi komunikacijski sistemi i sredstva kao što su: fiksni i mobilni telefon, internet, viber, skajp i slično. Početak svakog kvalitetnog komunikacijskog procesa počinje definiranjem cilja u aktuelnoj situaciji komuniciranja. Komunikacijski sadržaj, odnosno, njegova semantička vrijednost zavisi od toga radi li se o prvom kontaktu $\mathrm{s}$ recipijentom (osobom u stanju zdravstvene ili socijalne potrebe) ili o nastavku već započete komunikacije, kao i o cilju aktuelnog razgovora. $\mathrm{U}$ radu liječničkog tima to može biti, naprimjer, prikupljanje amnestičkih podataka, davanje informacija o dijagnostičkim i terapijskim pristupima, razrješenje nesporazuma, saopćavanje neugodnih informacija i slično.

Osoba koja započinje komunikaciju, treba u početnoj fazi uspostaviti kvalitetan komunikacijski odnos s osobama i nastaviti taj proces stalnim usklađivanjem i prilagođavanjem nizu aktuelnih okolnosti koje će se pojaviti u određenom trenutku. Usklađivanje je vezano uz određene specifičnosti osobe s kojom se uspostavlja komunikacija, kao i uz određene vanjske okolnosti. Kulturalni kontekst je jedan od osnovnih elemenata u tom procesu. Važno je prepoznati i uvažiti sve specifičnosti sagovornika: određene karakteristike na planu ličnosti, njegove vrijednosti, stavove, uvjerenja, obrazovnu razinu i znanje vezano za sadržaj razgovora. Treba, također, znati i uvažavati činjenicu da lični doživljaj stvarnosti u aktuelnom kao i širem kontekstu nije isključivi odraz stvarnosti, nego subjektivni doživljaj, lična slika stvarnosti, te da komunikator i recipijent imaju svoje lične slike stvarnosti, koje se ne 
moraju preklapati. Aktivnim slušanjem primamo korisne informacije, izbjegavamo nesporazume i konflikte, pokazujemo da nam je stalo do sagovornika, pomažemo osobama s kojima komuniciramo da jasnije sagledaju problem, i na kraju, izgrađujemo odnos povjerenja. Vještina slušanja podrazumijeva mnogo više od sposobnosti da ,čujemo poruku“. Aktivnim slušanjem izbjegavamo prepreke u komunikaciji i poštujemo tuđa mišljenja, stavove i osjećanja - drugim riječima, poštujemo integritet osobe koju slušamo. Slušanje kao dio komunikacijskog čina, omogućava da se poruke saslušaju, razumiju i tako otkrije njihovo značenje, zbog čega aktivno slušanje, osoba treće životne dobi, traži puni angažman, pozornost i potpunu uključenost $\mathrm{u}$ komunikacijski proces.

\section{LITERATURA:}

1. Ageing and Society, ISSN: 1710-1107; ISSN: 0714-9808, Cambridge University Press, Cambridge.

2. Dervišbegović, M. (2001) Socijalni rad, teorija i praksa, III dopunjeno i izmijenjeno izdanje, Studentska štamparija Univerziteta u Sarajevu, Sarajevo.

3. Duraković, Z. (1990) Medicina starosti, Medicinska naklada, Zagreb.

4. Mesić, E. (2013) Komunikacijske vještine u teoriji i praksi, Bihać.

5. Gahaghan, Judy. (1975) Interpersonalno grupno ponašanje, Nolit, Beograd.

6. Gregurek, Rudolf. (2011) Psihološka medicina, Medicinska naklada, Zagreb.

7. Hall, E. Nemi jezik, BIGZ, Beograd, 1976.

8. Hodoba, D. (1995) Mentalni poremećaji starosti, U: Muačević, V. i dr. (Ur.); Psihijatrije, Zagreb: Medicinska naklada, 521-538.

9. Kocijan - Hercigonja, D. Despot - Lučanin, J. Komunikacijske vještine u radu zdravstvenih djelatnika, Ministarstvo zdravstva i socijalne skrbi, Zagreb, 2004.

10. Klaić, B. (1978) Rječnik stranih riječi, Nakladni zavod Matice Hrvatske, Zagreb.

11. Lemme B. H. (1995) Development in adulthood, Boston, Allyn and Bacon.

12. Macieira-Coelho A. (2003) Biology of aging. Prog. Mol. Subcell. Biol. Progress in Molecular and Subcellular Biology 30: III-VI, 1-189. 
doi:10.1007/978-3-642-18994-4 1. ISBN 3-540-43827-0. PMID 12494760.

13. Macieira-Coelho, J. Gerontol Geriatr Res 2016, Journal of Gerontology \& Geriatric Research, Sažetak, 5: 6 DOI: 10.4172/21677182. 1000369 .

14. Petrović, M. (UGent) (2018) Gerijatrija: prema profesionalnim $i$ edukacionim standardima, Biomedicinska istrazivanja. 9 (1). p. 112 116.

15. Pennington, Donald. (1997) Osnove socijalne psihologije, Naklada Slap, Jastrebarsko.

16. Reardon, K.Kathleen. (1998) Interpersonalna komunikacija - Gdje se misli susreću, Alinea, Zagreb.

17. Rusac, Čizmin. (2011) Nasilje nad starim osobama u ustanovama, Med Jad, (2011); 41(1-2):51-58 Zagreb, ISSN 0351-0093.

18. Schultz von Thun. (2001) Kako međusobno razgovaramo, Erudita, Zagreb.

19. Schaie, W.K.,Willis, S.L. (2001) Psihologija odrasle dobi i starenja. Jastrebarsko: Naklada Slap, Zagreb.

20. Willis, SL, Cornelius, SW, Blow, FC, \& Baltes, PB (1983) Trening istraživanja o starenju: Pozorni procesi. Časopis za obrazovnu psihologiju, 75 (2), 257-270. http://dx.doi.org/10.1037/00220663.75.2.257.

21. www. Diskriminacija.ba; preuzela 26. 11. 2019.: Institucija ombudsmena za ljudska prava Bosne i Hercegovine, (2010) Specijalni izvještaj o stanju ljudskih prava starih osoba.

22. Šarić, Družić. (2016) Socijalna gerontologija - naučna knjiga, OFFSET, Tuzla.

23. Škiljan, D. (1978) Govor realnosti i realnost jezika, Školska knjiga, Zagreb.

24. Zijad Duraković- MEDIX • LISTOPAD/STUDENI 2013 • GOD. XIX - BROJ 107/108 • WWW.M E D I X .C O M.H R. 


\title{
THE IMPORTANCE OF INTERPERSONAL COMMUNICATION \\ IN THE PROCESS OF PROTECTION AND CARE OF THE OLDER PEOPLE
}

\author{
PhD Emin Mesić, International University Travnik \\ E-mail:tvusk@net.hr \\ PhD Sena Družić, Islamic Faculty of Pedagogy \\ University of Bihać \\ E-mail:sena_druzic@yahoo.ca \\ PhD Mirsada Terzić-Avdagić
}

Abstract

Communication, as a social phenomenon, depends largely on the number of participants exchanging messages, as well as their interaction, which takes place at the intrapersonal and interpersonal levels. The aim of this scientific work was to investigate, analyze and present facts, which are important for communication relations in the process of protection and care of the elderly people. In any situation in which a person is the main subject of the communication process, communication that focuses on the individual's internal behavior should not be neglected that is, in-person communication or talking to yourself. In everyday communication, most people pay the utmost attention to what is being said, without considering how it is said. Is it necessary to remind that a beautiful word, with a smile, breaks all barriers in buman communication. This can be extremely healing for those who are in their third age and who are referred to the help of others. The method of theoretical analysis was used in the research, and research on the importance of interpersonal communication in geriatric and gerontological institutions was presented. The study showed a positive observation, highlighting the attitude of employees of residential care facilities and their full commitment to service users in their best interests, and the humane attitude and respect for their dignity, as highlighted by numerous service users in their statements institution.

Keywords: interpersonal communication, receptionist, empathy, geriatrics, gerontology, the elderly people. 


$$
\begin{aligned}
& \text { الدكتور المحاضر أمين مسيتش دولش } \\
& \text { جامعة دولية في ترافنيك المن مستو } \\
& \text { E-mail:tvusk@net.hr } \\
& \text { الدكتور المحاضر سيدة سنا دروزيتش } \\
& \text { جامعة بيهاتش سيدة ساضن } \\
& \text { E-mail:sena_druzic@yahoo.ca } \\
& \text { الدكتور المحاضر سيدة مرسادة ترزيتش آوداغيتش }
\end{aligned}
$$

\section{أهمية التواصل بين الأشخاص في عملية حماية الطسنين ورعايتهم}

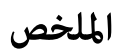

يعتمد التواصل، كظاهرة اجتماعية، إلى حد كبير على عدد المشاركين الذين يتبادلون

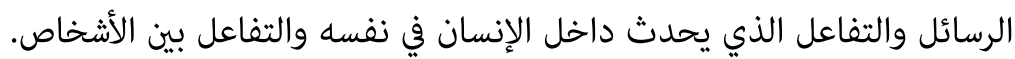

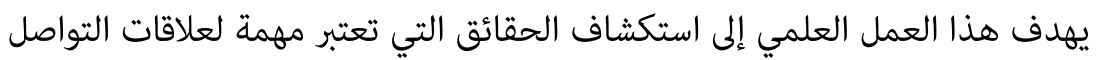
في عملية حماية المسنين ورعايتهم وعرض هذه العمل العن الحقائق وتحليلها.

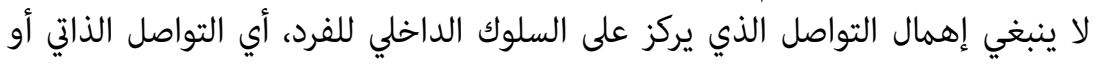

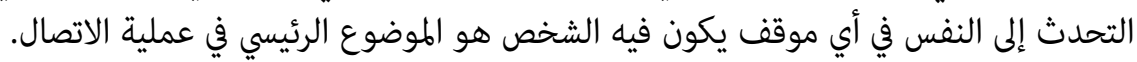

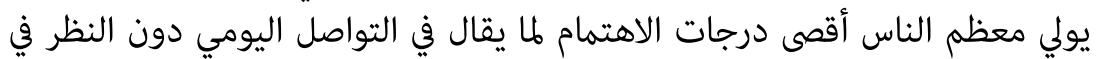

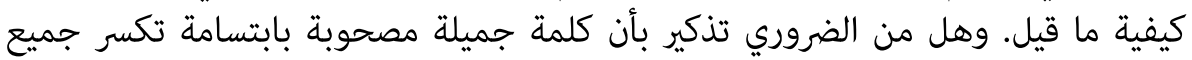

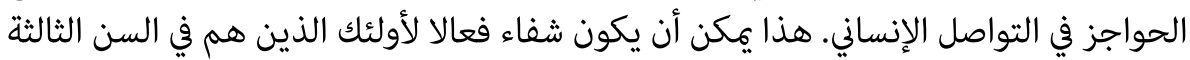
والذين هم بحاجة إلى مساعدة الآخرين. سلك الباحث طريقة التحليل النظري في البحث ، مساعة ، وقدم تقريرا عن أهمية التواصل

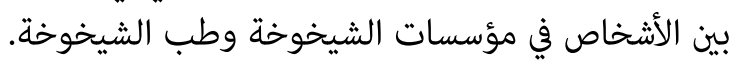

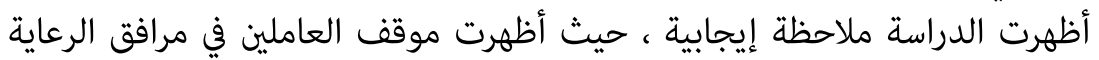

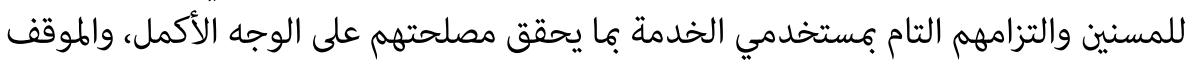

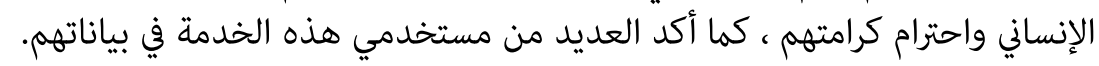

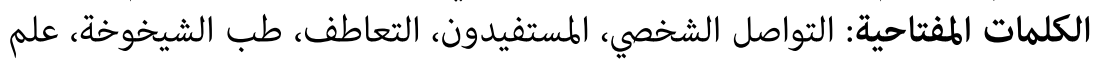

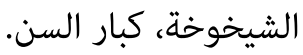

